\title{
HLA-A Gene Product
}

National Cancer Institute

\section{Source}

National Cancer Institute. HLA-A Gene Product. NCI Thesaurus. Code C113513.

A protein encoded by the human HLA-A gene. 